Alicante Journal of English Studies / Revista Alicantina de Estudios Ingleses

ISSN: 0214-4808 | e-ISSN: 2171-861X

Special Issue: Theatre and Performance Studies in English

No. 35, 2021, pages 101-117

https://doi.org/10.14198/raei.2021.35.05

\title{
Performative Encounters: Memory Violence in Sleep Deprivation Chamber ${ }^{1}$
}

Paula BARBA GUerRero

\begin{abstract}
Author:
Paula Barba Guerrero

Universidad de Salamanca, Spain

paulabarbaguerrero@usal.es

https://orcid.org/0000-0003-4214-067X

Date of reception: 15/02/2021

Date of acceptance: 14/06/2021

Citation:

Barba Guerrero, Paula. 2021. "Performative Encounters: Memory Violence in Sleep Deprivation Chamber" Alicante Journal of English Studies 35: 101-117.

https://doi.org/10.14198/raei.2021.35.05

(C) 2021 Paula Barba Guerrero

Licence: This work is licensed under a Creative Commons Attribution 4.0 International License (CC BY 4.0)

\section{(C) (1)}

\begin{abstract}
:
In their biographical play Sleep Deprivation Chamber (1996), Adrienne Kennedy and her son Adam P. Kennedy retrace family memories to describe the aftermath of police brutality in 1990s America. They narrate the brutal beating of a middle-class, young Black man named Teddy and the events taking place later at trial. The playwrights make use of "memory violence" (Olick 2018) to elicit the spectators' emotional response and construct a performative encounter in which the figures of perpetrator, survivor and bystander are questioned and redefined. Through this violence of remembering, they manage to insert unrecorded moments of abuse in our collective imaginary, moving from staged nightmares, distant courtrooms and individual sleep deprivation chambers into a figurative shared space where Black lives do matter.
\end{abstract}

Keywords: Adrienne Kennedy; Memory Violence; Black Lives Matter; Reparative Drama

1 The research carried out for the writing of this paper has been co-funded by the Junta de Castilla y León and the European Social Fund (Operational Program 2014-2020). This work has also been supported by the Spanish Ministry for Science and Innovation through the research project "A Critical History of Ethnic American Literature VI" Ref. No. PID2019-108754GB-100. Their support is hereby gratefully acknowledged. 


\section{Introduction: Performing Memory Violence}

In her 2018 Theater Hall of Fame address, Adrienne Kennedy speaks movingly of the influence of literature and art as taught by her parents. Kennedy explains how her upbringing shaped her interests as well as her worldviews, and elegantly reminds her audience of "the power of the stage" (in Kennedy 2019, n.p.). In her speech, she briefly looks back on her childhood and remembers her parents: "They took me everywhere," the playwright recalls, "they told me stories: A. Philip Randolph, W.E.B. Du Bois, Marian Anderson and Langston Hughes. My mother gave me a library card when I was five. They gave me a book of Gilbert and Sullivan operas, piano lessons and they always talked about the condition of American blacks" (in Kennedy 2019, n.p.). Kennedy's family memories are emotive and personal, and also mired in social uncertainty and implied violence. It seems that the more the playwright focuses on treasuring her childhood memories, the more discernible her menacing background becomes-her transformative literal and literary journeys set between the 1930s and 1960s in an America defined by racial terror.

Family memory, in this particular case, responds to a crisis of signification that takes place when the official narratives that serve to memorialize the past fail to represent one's family history. And, as such, it gains political meaning as it opposes affective politics to systemic power structures, and disputes official versions of the past. Kennedy's childhood memories contrast sharply with official American history as they situate Black experience at the center of a historical narrative that has consistently disregarded African Americans. These memories are family relics and, as such, they hold the potential to challenge the hegemonic erasure of others from national narratives, as well as the manipulation of spaces and temporalities of history-writing (Boyarin in Olick 2003a, 3). Kennedy is well aware of this, and in her drama, she draws from her family biographies to understand her childhood and debunk political mythologies. Specifically, she claims, "I write about my family [...] I see my writing as being an outlet for inner psychological confusion and questions stemming from childhood" (Kennedy and Lehman 1977, 42). Her plays, to this end, bear the responsibility for representing, both visually and materially, "the virtualities of childhood" (Davidson 2009, 332), thereby addressing ambiguous emotion as well as processes of memory re-structuring. And, because it is defined by memory, the playwright's creative process becomes an act of documentation and history re-writing through which the subject re-imagines her past in order to secure a present, and achieve self-definition, however painful that may be.

Kennedy's genealogy retraces steps in order to repair the social life and transmission of cultural memory in a time when, in the words of Duncan Bell (2009, 
346), "the past haunts the contemporary imagination", Imani Perry extending this notion to say that it also hunts it $(2019,111)$. For memory does not simply store past violence and haunt the self. Memory possesses its own kind of violence. In its clash with legitimized versions of history, memory can become violent in itself as it "violates and transgresses [...] our sense of order [and] integrity" (Olick 2018 , n.p.). It becomes threatening because it contests rather than reaffirms or reifies. Remembering violence therefore implies re-living traumatic events, which might shed some light on contemporary debates on the legitimacy of Civil War commemorations in the US, for instance. Jeffrey Olick furthers this argument in his examination of the memory-violence correlation, first outlining a change of paradigm in our perception of what violence is and what it entails for others beyond physical wounding; then, reintroducing memory as "a way of ascribing meaning to what has happened in history, [...] a way to redeem suffering in some fashion or other" (2018, n.p.). His views thus complicate notions of memory (and) violence, because, if it is we ourselves who assign meaning to past events-always in retrospect and via introspection while conversing with prior discourses-then, how do we, as a society, decide when/if violence is legitimate? $?^{2}$ Which forms of memory (individual, collective, public, emotional, traumatic) are to be inscribed in the fabric of history? And (how/when) should we represent them in art and culture? These are some of the concerns this article aims to throw some light on.

\subsection{Memory and Violence in Sleep Deprivation Chamber}

Adrienne Kennedy's work has often been considered ambiguous and unsettling. Its characters are contradictory, its racial stand is not always definite. This is because, in most of her plays, Kennedy performs memory violence as a source of affective ambivalence. The playwright understands memory's potentialities and draws on family biographies to call for historical and individual re-signification. Plays such as Funnyhouse of a Negro (1964) and The Owl Answers (1965) evoke memory as a liminal stage in which "identity secrets" can be discerned, re-possessed and articulated via memory artifacts. Or, as the playwright herself acknowledges in her autobiography People Who Led Me to My Plays $(1987,96)$, "[s] oon I would understand that I was in a dialogue with the photographs, prints, postcards of people. They were my alter egos." For this reason, some scholars perceive in Kennedy's work a taste for intermediate spaces and racial interdependence. More specifically, authors such as Werner Sollors see in her plays "mysteriously divided and related characters [that] repeat sentence sequences" in the midst of an "enigmatically ambiguous action" (1991, 508). Others, like Patti Hartigan, understand Kennedy's work as

2 For examples of socially legitimized forms of violence, see Olick (2018). 
an attempt at building realities where "romantic innocents are threatened by the persistent presence of racism" $(2000,112)$, exploring the inevitability of violence as an ideological cause of suffering, and the historical effect of social injustice maintained over time. Like his mother's, Adam P. Kennedy's drama is also very autobiographical, and contingent on experience and, especially, family relics. This article consequently reads the Kennedys' reliance on (family) memory not as an attempt at sanitizing or correcting public memory through the exposure of subjective pain and the total erasure of memory's violent parts, but as a careful meditation on the aftermath of memory violence that, when being performed, accounts for the suffering of those who live (and re-live) violent events in/through history, thereby calling for solidarity networks and active social intervention. It is my contention that Kennedy sets her writing efforts directly against "legitimating traditions" (Olick 2003a, 1) in a bid to reconsider the role of active witnessing and the rhetorical reproductions of oppressive discourses onstage as a creative means to unravel the mnemonic potential of violent theater acts.

Specifically, this article studies the notion of memory violence in the 1996 play Sleep Deprivation Chamber, which Adrienne Kennedy co-wrote with her son Adam P. Kennedy. The play narrates the brutal beating of a middle-class, young Black man named Teddy and the events that take place later at trial. After the attack, Teddy is accused of having assaulted his assailant, a police officer, and has to prove his innocence in court. With Adrienne Kennedy's characteristic blend of shock and surrealism, and both playwrights' autobiographical styles, Sleep Deprivation Chamber examines the dehumanization and vilification of blackness in America. It explores the abjection imposed on Black bodies as markers of difference and exclusion that are experienced as subjective horror, in Kristevan terms (1982). It also probes the memory scars these experiences leave on cultural and political bodies, social communities and statist power structures in an attempt to foster public recognition and, possibly, empathy. In contrast to most of Adrienne Kennedy's plays and the memories mentioned in her 2018 speech, this co-written work is not set in the period between the 1930s and 1960s, her usual source of inspiration (Vorlicky 1997, 67). Instead, it tells the more recent beating of her son Adam and the family's involvement with the criminal justice system-to clear his name-afterwards. It connects with recent debates on the status of Black lives in the US, siding with ideologies now summed up by the Black Lives Matter movement. ${ }^{3}$ Making a conscious use of

3 Adrienne Kennedy "never wanted to identify totally with women playwrights or Black playwrights or anybody." She did not "write for a total audience" or believe in segregation in the theater. Instead, she "wanted to communicate with people," those who made her suffer at Ohio State, and those who did not (Kennedy and Binder 1985, 107-108). This 
fictional devices, Adrienne and Adam Kennedy share their memories of the event to address racial disparities and injustices in America (Parks and Kennedy 1996, 45). They delve into family memories to "represent and invent what [they] can no longer spontaneously experience" (Olick 2003a, 3) and denounce the political systems that allow and, indeed, feed on racism. These invisible structures result in adapted forms of pre-emancipatory violence, which Philip C. Kolin bluntly describes as "highway apartheid" (2007b, 4), such as racial profiling, brutal aggression or even murder. To counter these, the play contests racial impositions of silence and invisibility and turns the theater into a "third space" where "objects of otherness" are identified and vindicated (Bhabha 1990, 211). Sleep Deprivation Chamber adheres to Audre Lorde's desired "transformation of silence into language and action" (2017 [1977], 1), voicing memory, violence and their contemporary aporias to challenge audience complicity in sustaining degrees of oppression, the legitimized (ab)use of gun-force and urban states of insecurity.

\section{Courtroom Rhetorics in the Theater of Memory}

To say that African Americans are at considerable social, economic and political disadvantage is nothing new. Black populations now constitute a disproportionate percentage of imprisoned, murdered and impoverished people. The fact that they systematically face extremely violent responses from police authorities is similarly known, and is further verified by the massive number of arrests and the excessive use of force shown during the 2020 Black Lives Matter protests-which far exceeded the same police tactics at the US Capitol riots in January 2021 (Tolan 2021, n.p.). Yet, the extent to which these practices rely on a rhetoric of structural injustice and racial inferiority - and, more particularly, the possibility of contesting and, conceivably, undoing its logic through literature and performance-is in need of further analysis. Much has been said about police brutality in America. From outraging statistics to excruciating testimonies, the sore aftermath of lethal force in the US is undeniable. And yet, Olick states (2018, n.p.), citizens continue to be partially complicit in state violence; legitimizing bloodshed for protection and justifying it when exerted against those deemed a threat. Chandan Reddy (2011) explores this, considering it "violence from freedom," and commenting on the tendency to accept brutal-

is partly the reason why she was not included as a Black Arts playwright-other reasons being the fact her plays are not fully affirmative of Black identity and her being a woman. Yet her political views, as presented in her plays, do coincide with the tenets of the Black Lives Matter movement. This is perhaps most evident in Sleep Deprivation Chamber, where she and her son examine the lack of public accountability and the certainty of police brutality in modern-day USA. 
and even deadly — force to defend the integrity of the body (politic). Discourses on national protection have commonly been used to justify acts of violence that are neither legitimate nor admissible, for, as Olick points out, the fact that the use of violence is conditionally legitimized is not the same thing as making "use of legitimate violence" (2018, n.p.; italics in original). In other words, whilst using conditional violence might seem acceptable and necessary in certain situations, the legitimization of all violent acts is contingent upon circumstances. ${ }^{4}$

The role literature and the arts play in signifying injustice is therefore crucial to elicit feelings of "co-resistance" (Kricorian 2015), making audiences witness the characters' struggles and fostering an emotional urge to join them in their fight for justice. Plays can foster social situations that elicit public comprehension, recognition and a desire for solid active change. This is, indeed, the purpose behind Adrienne and Adam Kennedy's play. The authors aim to raise awareness of the inevitability of police brutality, which seems to have infected most social geographies. In an interview with Patti Hartigan (2000, 113), Adrienne Kennedy explains that she never expected her son to be assaulted by a police officer. She elaborates on the illusion of their family's "white house with yellow shutters" and the false fantasy of protection it conveyed to them before the attack (Hartigan 2000, 113). However, she also contends that, later on, she realized that these assaults happen "all the time" (Parks and Kennedy 1996, 45). In fact, almost thirty years after the publication of Sleep Deprivation Chamber, police abuse remains an imperative danger for African Americans. The intention of the play, then, is to make this problem known, seen and publicly acknowledged, which the playwrights make possible by mimicking a courtroom rhetoric that undoubtedly exposes the biases behind it.

In the play, space is negotiated as a speaking organism that stores and administers political meaning. The authors recreate traumatic space in both realistic and oneiric scenes to comment on the emotional, psychological and physical after-effects of this type of violence. Places in Sleep Deprivation Chamber are, therefore, real sites-the stage, the theater building-imbued with intimate memory and familiar architecture-the family house, the street, the neighborhood, Antioch College, Ohio, etc.-and, as Tonya Davidson contends (2009), they remember and haunt the people within, while embodying multiple memories of characters, authors and spectators. In the performance of the Kennedy's family memories there exists an embedded collective memory that the playwrights bring to the fore in order to assess social assumptions and expectations. Sleep Deprivation Chamber works at different semiotic and semantic levels, making use of intertextual devices, and meta-theatrical

4 For common situations in which violence is publicly accepted, see Olick (2018). 
strategies that open up new interpretations for both the referenced sources, and the real events described. One such example would be the meta-performance of Shakespeare's Hamlet in the protagonist's classes. Suzanne, the protagonist, is a drama professor at Antioch College. She is also the mother of Teddy, who is brutally assaulted. By entwining the plot of Hamlet with that of Teddy's aggression, the Kennedys combine biographical memory with the imagination, with oneiric experiences and with nightmares. They hint at desperation through a mention of Ophelia who, in her madness, could also be said to operate from a liminal and limited threshold. The play makes use of these elements to explore and revise the characters' feelings of insecurity inasmuch as they are representative of the biopolitics at play. The performance thus becomes a figurative encounter where the conventional categories of victim, perpetrator and bystander are reconsidered. These clearly demarcated figures meet onstage and merge with one another via emotion-primarily empathy_breaking dramatic expectations to offer alternative responses to brutal violence. Peggy Phelan states that performance is short-lived and only exists in the present, that it "cannot be saved, recorded, documented, or otherwise participate in the circulation of representations of representations" (1993, 146; italics in original) as it escapes systemic reproduction and indulges in mimicry instead. If she is right in this assertion, then, it is in its organic disappearance after each new representation that performance contests our social economies since it works as a liminal, temporal encounter where most categories are dissolved in the name of deconstruction and revision.

Furthermore, Sleep Deprivation Chamber carries a space in its title. One that is capable of evoking nightmares, of making the protagonists lose sleep, and, maybe, of opening up the possibility of social change through a semi-Artaudian exposure of violence (1958). This non-representational space is a figurative rendition of the human psyche, a conceptual place where trauma memories are symbolically stored. Nonetheless, through its onstage performance, it becomes a real space that not only retains symbolic meaning but also operates as a material platform for social complaint and change. In this represented allegorical space, the injustices of a discriminatory penal system can be exposed, criticized and condemned. Adrienne and Adam Kennedy's sleep deprivation chamber is a room defined by the fracture of the fantasy of protection their actual home projected; it is a staged space that figures as an emotional prison that cannot be escaped in the play. This chamber is not simply an enclosed space where characters are interrogated. The room also makes reference to the characters' mental spaceparticularly the mother's - and their incarceration into a painful sequence that they seem to experience in a loop. For Suzanne this implies dreaming of bloody crime scenes represented on stage, imagining her son being beaten in various 
scenarios and, also, writing letters. This figurative representation of uncertainty and insecurity is heightened by the intertwined references to the plot of Hamlet, the presence of a figurative ghost (of memory), and the meta-fictional rehearsals of The Ohio State Murders, another of Adrienne Kennedy's plays, performed by Suzanne's drama students (Kennedy and Kennedy 1996, 21).

Performed space constitutes an essential part in Kennedy's drama in general, and in this co-written play. It is not simply that the playwright names some of her plays after alternate spatial figurations of the paradigmatic prison (the fun(ny)house, the private rooms, the chamber)—which, as Eduardo Mendieta remarks (2004), point to the same shared social topography as do the prison, the plantation and the ghetto-but Kennedy herself has a deep connection with the spaces she considers to be tainted by history. In an interview with Suzan-Lori Parks, Kennedy explains that, for her, the space where she writes is important: "I love the architecture of New York. The architecture. I feel immersed in... really profound history," she remarks $(1996,45)$. And, although she uses this to explain her return(s) to the Upper West Side, her statement also hints at her personal understanding of space as a bearer of memory; not an empty signifier, but a political category that stores and, in each representation, restores and retells the past.

Similarly, the occupation of space by the protagonists portrays distinct forms of entrapment. Whereas Suzanne is stuck, permanently "motionless" writing letters that never receive an answer (Kennedy and Kennedy 1996, 44), Teddy is constantly shifting settings, from interrogation rooms to the court chamber, police offices, his father's porch and his own car, just to name a few. Their enactment of trauma is therefore different; Suzanne's performance depicting emotional distress, best illustrated by her nightmares, while Teddy's concatenated actions are but a physical re-enactment of traumatic shock. Unexplained gaps between scenes similarly underline this conception.

Their family wounds are also depicted in the play through metaphorical references to natural disasters. The pain of discrimination, exclusion and racism is examined through symbolic representations of catastrophes and collapse. One such example is Teddy's uncle's claim that "The Bay Fall Bridge is fallen. We live near the epicenter" (Kennedy and Kennedy 1996, 64). With this statement, the character reveals the extension of the damage caused by brutal violence and introduces it in the form of symbolic reverberations that reach the entire family unit. As the character clarifies, they are located "near the epicenter" and cannot escape its effects. In this example, Teddy's assault is described as a real earthquake, shaking the ground beneath the characters' feet. Yet, these symbols are not the only representations of racial violence. The courtroom rhetorics alluded in this section's title are perhaps more conspicuous in the literal performance of onstage interrogations: 
UNSEEN QUESTIONER: So when he hit you, you didn't go to the ground? TEDDY: I went to the ground when he first hit me and then that's when he proceeded to drag me across the driveway while he was kicking me and hitting me.

UNSEEN QUESTIONER: Well, what position were you in when he first started to drag you?

TEDDY: I was basically crouched on the ground.

UNSEEN QUESTIONER: You were in a crouch?

TEDDY: Well, crouch maybe-I was bending when he hit me I sort of - I moved to the ground-I was bending at the knees and he put his hand behind me and proceeded to drag me across, all right (Kennedy and Kennedy, 1996: 9).

Here, Teddy is forced to re-live an event whose effects he has not yet fully processed in order to provide his unseen questioner with details of his assault. The coldness of their encounter and questions, together with the unknown name, face and character of the questioner, seems to suggest indelicacy and lack of basic empathy, which is later complemented by (and revisited in) a nameless student actor's more direct asking " $[\mathrm{t}]$ his is what they teach at the police academy? This is the police manual?" (Kennedy and Kennedy 1996, 24). His rhetorical questions are there for the audience to reply to.

This urge to make the audience react is also perceived in Suzanne's letters to various political authorities, in which a progressive change of tone suggests a transformation in the character's perception of the governing powers. Her letters are Suzanne's way of intervening in an uncertain situation that causes her insecurity and that is out of her control: her son is suffering and in the middle of a trial for an assault he did not commit. Yet, in her progressive adaptation of her tone-from hope to disillusionment; from specific real details to the account of her dreams (Kennedy and Kennedy 1996, 7-31)_one can also identify the character's embrace of her deeply traumatic emotional state, pointing to a reality on the verge of ontological collapse. After all, Ben Brantley is not without reason when he states that in Sleep Deprivation Chamber reality and fantasy meet and "meld into a prison of the mind" (1996, n.p.).

All the spaces in the play are particularly significant because they respond to a rhetoric of surveilled topographies. This discourse, though, is not exclusive to contemporary fiction, but has been a repeated, versatile trope in African American literature since time immemorial. One that responds to the existence of structural forms of oppression and their consequent administration of national space. Connected to these surveillance politics and their political implications is the playwrights' decision to introduce in Suzanne's letters a classic convention of slave narratives: the ratification of the speaker's reliability, morality and good 
intentions. She informs the Governor that "[a]ll our lives we have tried to fit in American society and improve our society" (Kennedy and Kennedy 1996). Black writer Ishmael Reed (Carter Harrison et al. 2012, 93) sees in this modern replica of demonstrating narrative reliability a fear of facing the kind of white jury "who acquitted the men who killed Emmet Till," and, by extension, of all those law enforcers who have murdered Black individuals like Breonna Taylor, and more recently, George Floyd. Reed's interpretation points to the extension of dramatic action beyond the limits of the play's narrative frame. This convention is also used in Suzanne's letters to Governor Wilder, and it is interesting, first, because it serves to establish deep connections between the institution of slavery and police brutality in contemporary US settings, and, second, because it progressively subverts reliability politics to denounce racial bias. The first letter opens with a statement underlining the respectability of its writer and her family: "We are an outstanding Black American family. My former husband, David, is head of Africa/USA. My plays and stories are taught widely" (Kennedy and Kennedy 1996, 8). In Suzanne's opening, it is easy to identify a desire to account for the truthfulness of the family's testimony by introducing herself and her family as good-non-violent—citizens and, hence, reliable narrators. This urge is perhaps informed by a fear rooted in the historical questioning of Black testimonies (albeit modernized), which is similarly addressed in slave narratives such as those of Harriet Jacobs and Frederick Douglass. And it is particularly significant because it serves to establish links between slavery and the present. This correlation is even more evident in the following statement, "[w]e are now a grieved family. Our son is being persecuted by the Arlington Police Department just as surely as happened in the Deep South in the 1930s or during Emmet Till's time" (Kennedy and Kennedy 1996, 8), where Suzanne traces a chronology of injustice to firmly condemn abuses against Black peoples in front of her audience. Thus the play's representation of trans-historical precarity serves a dual purpose: to lay bare the characters' vulnerability in the face of unjust situations, and to raise feelings of accountability in their spectators. As such, then, these connections are testimony to the magnitude of America's often-denied "race problem."

The archeological project of Sleep Deprivation Chamber therefore depends on a biographical rendering that later develops into dramatic storytelling, and social complaint. The Kennedys insist on introducing Teddy to the audience through his "achievements as a student leader" (Harrison et al. 2012, 93). He is presented as a brutalized, non-violent citizen: "On Friday night, January 11, my son, a fine citizen who has never been in any trouble whatsoever, was knocked to the ground and beaten in the face, kicked repeatedly in the chest and stomach and dragged in the mud by an Arlington Virginia policeman whose name is Holzer" (Kennedy and Kennedy 
1996, 8). ${ }^{5}$ As mentioned above, the detail with which the protagonist recounts her son's brutal assault shows conventions of slave autobiographies. However, it is worth noting that, while slave narratives do this to frame the author's legitimacy, in Sleep Deprivation Chamber its aim is to challenge racial bias. Through mimicry and emotional distancing, Suzanne revises this convention to build empathy and dramatic tension. Hers is not a letter seeking to convince the Governor of her son's reliability. Rather, it is demanding accountability and recognition for the violence and injustice he endured. In each new letter, the protagonist makes reference to the murder of Emmet Till, comparing it to her son's beating and constantly reminding her audience of the existence (and persistence) of racial profiling. This allows for a revision of both reality and fiction which questions the characters' actions and words, and also the real situations that they mimic. ${ }^{6}$

In terms of form, the play is equally transgressive. Seen by Elin Diamond as "a concatenation of dreams, texts, enactment and voices" (2007, 666), Sleep Deprivation Chamber makes use of original dramatic strategies that, along with Adrienne Kennedy's surrealist aesthetics, turn the stage into a site of simultaneous witness and repair. Kennedy, as Kolin remarks (2007a, 62), builds "surrealistic dreamscapes [where] the voice of history is so strong" that the characters react physically to the exclusion from the public sphere. These performances serve for her to combat racism onstage (Kolin 2007a, 63), forcing her audience to react to the violence to which they are exposed. Nonetheless, it is language that redeems the protagonists from historical impositions and injustice, in the end, transforming the stage into a site and a theater of memory.

\section{Reparative Representations of Uncertain Spaces}

Sleep Deprivation Chamber explores the after-effects of memory violence to discern family memories as sources of emotional knowledge. Such memories are the traces of violence that Katharina Schramm claims $(2011,5)$ have "profound effects on individual consciousness as well as collective identifications." This connection between individual/family memory and public remembrance is

5 This concern is shared by Imani Perry in her epistolary biography Breathe: A Letter to My Sons, where the author presents her children as "people. Black boys. People," "not a problem" (2019, 1). A contention similarly presented by Kennedy in, for instance, Suzanne's phrasing " $[\mathrm{m}] \mathrm{y}$ son has never been in any trouble at all. He is a fine citizen and student at Antioch College" (Kennedy and Kennedy, 1996, 8).

6 The use of repetition in Sleep Deprivation Chamber falls close to Suzan-Lori Parks' original dramatic mechanism of repetition with revision, formally known as "Rep\&Rev" (Parks 1995a, 9), where the characters progressively revisit their words (and actions), accessing new meaning in their rewriting of the past through literature (Parks 1995b, 4). 
similarly examined by Claudia Barnett who, drawing on Chezia ThompsonCager's analysis of Kennedy's work, identifies in the plays a disruption of the audience's position "as pacified observers or voyeurs" (Thompson-Cager in Barnett 1996, 152). Barnett $(1996,152)$ believes that, in presenting the audience with violent images, Kennedy "attempts [...] to awaken the collective memory of horror they have hitherto repressed-and to awaken it [in pure Artaudian terms (1958)] through the cruelty of recognition." Hence, to answer the questions that opened this study regarding the legitimization of violence and the representation of memory, Sleep Deprivation Chamber proposes the solution of exposing racial violence to foster emotional attachment, inscribing subjective forms of remembrance that are never recorded in the fabric of history and doing so violently, to shock society and elicit cultural intervention.

This realization that others are indeed vulnerable is particularly pertinent because family memory, Marianne Hirsch reminds us, "has [a] shared, tentative and vulnerable quality [whose] inherent visuality and contingency is exposed in pictures" that can be shared $(1997,127)$. That is, family memory-which is what interests Kennedy the most-is always a potential act of creative imagination led by the visual "fragmentary remnants" (Hirsch 1997, 127) of a shared past that require an audience. And, as we see-witness-them, we remember snatches of our collective history, distant echoes, bits and pieces that are reworked and resignified into narrative to make sense of a disjointed reality. This notion is similarly explored by Olick, who explains that, after the failure of (national) memory, a proliferation of alternative-subjective-memories and stories emerge (2003a, 3). Olick assesses the complex interrelation between public memory, history and the nation to conclude that there exist scattered memories that recall "unitary history," and also subversive testimonies that go beyond cultural relativism to contest a homogenizing rhetoric based on nationalist nostalgia (2003a, 3-4). These alternative accounts, Olick continues, transform memory into "a matter of explicit signs, [rather than] implicit meanings" (2003a, 3), which is the reason why testimony wavers "between victimhood and protest" (Edkins 2003, 9). We no longer make sense of the world through a single narrative that provides us with a shared collective identity and purpose, but rather make use of memory as a narrative platform informed by specific locations and cultures.

Olick's views are particularly relevant in/for theater, as signs in drama constitute the performance itself. The visual and discursive elements of a play are encoded in the cast's actions and can be interpreted as one of those "explicit signs" that are articulated to give concrete (and new) meaning to seemingly distorted truths. These memory traces are not solely incorporated as discourse in the Kennedys' play, but are also embedded in the dramatic spaces and objects onstage. Hence, it is the responsibility of the audience to discover the hidden meanings and stories 
that memory sites and artifacts conceal. In the play, these material articulations of collective memory are related to Teddy's assault, which is seen as a public spectacle and concern. This is because violence "lives on and through the monuments [and objects] marking it" (Olick 2018, n.p.), reproducing trauma injuries at a symbolic level. For us to disentangle the complex web of allusions and references made in the play, we must "enter into constructive" conversation with previous memory discourses, though, and reconsider the legitimacy of claims over the erasure and/or commemoration of certain pasts (Olick 2018, n.p.). Thus, as spectators of Adrienne and Adam Kennedy's stage, we become "captive observers," shocked by the brutality on stage, but no longer caught up in the machinery of "a society of the spectacle that manipulates [our] eyes"; knowing, as Geoffrey Hartman $(2004,258)$ explains, that " $[t]$ he mind's safe house is no longer safe." The fantasy of protection is broken, and it is through second-degree traumatization that we perceive "the geometry of memory" (Olick 2018, n.p.), which identifies a person's degree of participation, either as victim, perpetrator or mere bystander of our own social world.

In Sleep Deprivation Chamber, the playwrights retrace family memories to describe the aftermath of police brutality in 1990s America. They do so alternating realistic and surrealistic scenes where "dream sequences have fragments of the dream acted out onstage" (Kennedy and Kennedy 1996, 6; italics in original). These alternating realities indirectly comment on the process of trauma writing, and the need to share one's story in order to begin healing: the stage directions read "[l]ight on Teddy. He remembers as Suzanne writes" (Kennedy and Kennedy 1996, 7; italics in original). Hence, Suzanne's letter-writing — just like the Kennedys' playwrighting helps Teddy heal. For it is in her dreamscape that Suzanne responds to her son's desperate cries for help, offering "the Policeman" who hurt her son symbolic retribution in the form of "poison" (Kennedy and Kennedy 1996, 12).

\section{Conclusion}

In Kennedy's drama, as Jeanie Forte suggests, the spectator is usually forced to rethink their own position within a culture built around violence and forgetting, condemning structural racism as they reconsider their part in it $(1992,165)$. Hence, the Kennedys' work is emotionally challenging for both actors and spectators, writers and readers. Sleep Deprivation Chamber specifically navigates liminal affects and systemic cruelty to address social concerns that, unfortunately, continue to be as relevant as ever in a world in which Black lives are still lost daily to gunfire and deadly force. In the play, the authors interweave Teddy's testimony with his mother's letters in his defense, exploring the family's most intimate fears and emotions. They also entwine courtroom scenes with oneiric passages that point to the traumatic nature of their memories of both past violence and the violence of memory itself. 
It is precisely this interaction between memory and violence that has been the interest of this article, the many ways in which theater, as performance and as a performative act, can help survivors (and the general public) visibly enact trauma and revisit the ghosts of the past in a second act of witnessing, or "co-witnessing" (Kacandes 2001) perhaps, that mobilizes vulnerability and collective memory, and calls for accountability and the social recognition of pain. In exploring the impact of remembering violent pasts and, particularly, the violence of remembering (memory violence) as a creative mechanism, the play makes Black vulnerability visible and brings about feelings of solidarity and, possibly, social change.

In an attempt to build a "connective future" (Hirsch 2017, 223) where the feelings of dislocation and uncertainty that pervade Sleep Deprivation Chamber can disappear, the Kennedys resort to memory violence to elicit the spectators' emotional response and construct a performative encounter in which the figures of perpetrator, survivor and bystander are questioned and redefined. The audience unconsciously perform the role of bystanders, perpetrating a violence that is not fictional, but actually played out on many US streets. Similarly, the survivor of trauma becomes a patient observer who dissects the event in writing, and stages it to foster public recognition. The perpetrator is dispossessed of power and becomes a marginal figure as the survivor's story takes the stage. Through this violence of remembering, the playwrights manage to insert unrecorded moments of abuse in our collective imaginary and reclaim gun violence, police abuse and safety deprivation as global, and indeed feminist, concerns (Kendall 2020,16) that move from staged nightmares, distant courtrooms and individual sleep deprivation chambers into a shared space - the theater, the streets-where Black lives do actually matter, and are represented and recorded in stories (Sontag 2004, 28). If Ron Eyerman $(2004,163)$ is right to argue that "[f]ounding narratives are about creating, constituting, a collective subject as much as they are about creating an 'imagined' community," then, it is in theater that Adrienne and Adam Kennedy articulate the possibility of reparations, identity formation, cultural recognition and healing; of a fair tomorrow that rises from a disjointed world onstage.

\section{Works Cited}

ARTAUD, Antonin. 1958. The Theatre and Its Double. Translated by Mary Caroline Richards. New York: Grove Press.

Brantley, Ben. 1996. "Righting a World Out of Joint." New York Times. https://www. nytimes.com/1996/02/27/theater/theater-review-righting-a-wrong-in-a-worldout-of-joint.html [Accessed online on Jan. 14, 2017]

BARNETT, Claudia. 1996. '“This Fundamental Challenge to Identity': Reproduction and Representation in the Drama of Adrienne Kennedy." Theatre Journal 48 (2): 141-155. https://doi.org/10.1353/tj.1996.0047 
Bell, Duncan. 2009. "Introduction: Violence and Memory." Millennium: Journal of International Studies 38 (2): 345-360.

Внавна, Homi K. 1990. "The Third Space: Interview with Homi Bhabha." In Rutherford 1990, 207-221.

BRYANT-JACKSON, Paul K. and Lois More Overbeck, eds. 1992. Intersecting Boundaries: The Theatre of Adrienne Kennedy. Minneapolis: U of Minnesota P.

Carter Harrison, Paul, Edward Albee, Robert Brustein, Ishmael Reed, Evan Yionoulis, Marcus Stern, June Pyskacek, Evangeline Morphos, Estelle Parsons and Gerald Freedman. 2012. "Personal Perspectives on Adrienne Kennedy." Modern Drama 55 (1): 90-99. https://doi.org/10.3138/md.55.1.090

DAvidson, Tonya. 2009. "Remembering Houses: The Role of Domestic Architecture in the Structuring of Memory." Space and Culture 12 (3): 332-342.

https://doi.org/10.1177/1206331209337078

Diamond, Elin. 2007. "Mom How Did You Meet the Beatles? A True Story of London in the 1960s." Theatre Journal 59 (4): 666-667. https://doi.org/10.1353/ tj. 2008.0040

EDKIns, Jenny. 2003. Trauma and the Memory Politics. Cambridge: Cambridge UP. https://doi.org/10.1017/CBO9780511840470

Eyerman, Ron. 2004. "The Past in the Present: Culture and the Transmission of Memory." Acta Sociologica 47 (2): 159-169. https://doi.org/10.1177/0001699304043853

ForTe, Jeanie. 1992. "Kennedy's Body Politic: The Mulatta, Menses, and the Medusa." In Bryant-Jackson and Overbeck 1992, 131-141.

Hartigan, Patti. 2000. "Adrienne Kennedy: A Fragile But Ferocious African-American Playwright." The Journal of Blacks in Higher Education 28: 112-113. https://doi. org/10.2307/2678724

Hartman, Geoffrey. 2004. "Trauma within the Limits of Literature." European Journal of English Studies 7 (3): 257-274. https://doi.org/10.1076/ejes.7.3.257.27984

Hirsch, Marianne. 1997. Family Frames: Photography, Narrative, and Postmemory. Cambridge: Harvard U.P.

—. 2017. "Debts." a/b: Auto/Biography Studies 32 (2): 221-223. https://doi.org/10.1 080/08989575.2017.1288002

KACANDES, Irene. 2001. Talk Fiction: Literature and the Talk Explosion. Lincoln: University of Nebraska Press.

Kendall, Mikki. 2020. Hood Feminism: Notes from the Women White Feminists Forgot. London: Bloomsbury.

Kennedy, Adam P. and Adrienne Kennedy. 1996. Sleep Deprivation Chamber. New York: Theatre Communications Group.

Kennedy, Adrienne. 2019. "Adrienne Kennedy's Theater Hall of Fame Address." Speech given at the Theater Hall of Fame and produced by Canaan Kennedy, New York, November 2018. https:/www.youtube.com/watch?v=ff5E9HQ9G7E 
—. 1964. Funnyhouse of a Negro. In Kennedy 1988, 1-24.

—. 1965. The Owl Answers. In Kennedy 1988, 25-46.

—. 1987. People Who Led Me to My Plays. New York: Theatre Communications Group.

—. 1988. In One Act. New York: University of Minnesota Press.

—. 1990. The Ohio State Murders. New York: Samuel French.

Kennedy, Adrienne and Lisa Lehman. 1977. "A Growth of Images." The Drama Review 21: 41-48.https://doi.org/10.2307/1145135

Kennedy, Adrienne and Wolfgang Binder. 1985. "A MELUS Interview: Adrienne Kennedy." MELUS 12 (3): 100-108. https://doi.org/10.2307/467123

Kolin, Philip C. 2007a. "American History/African Nightmare: Adrienne Kennedy and Civil Rights." In Kolin 2007b, 62-82.

-, ed. 2007c. Contemporary African American Women Playwrights. New York: Routledge.

—. 2007b. "Introduction: The Struggles and Triumphs of Staging Gender and Race in Contemporary African American Playwrights.” In Kolin 2007b, 1-8.

Kricorian, Nancy. 2015. "Choosing 'Co-Resistance' Rather than 'Turkish-Armenian Dialogue," Armenian Weekly. https://armenianweekly.com/2015/05/22/coresistance/ [Accessed online on Nov. 5, 2020]

Kristeva, Julia. 1982. The Horrors of Power: An Essay on Abjection. New York: Columbia U.P.

LORDE, Audre. 2017. Your Silence Will Not Protect You. London: Silver Press.

MendietA, Eduardo. 2004. "Plantations, Ghettos, Prisons: US Racial Geographies” Philosophy \& Geography 7 (1): 43-59. https://doi. org/10.1080/1090377042000196010

Olick, Jeffrey. 2018. "From the Memory of Violence to the Violence of Memory." ENRS. https://enrs.eu/article/from-the-memory-of-violence-to-the-violence-ofmemory [Accessed online on Sept. 10, 2020].

-.2003a. "Introduction" in Olick 2003b, 1-16. https://doi. org/10.1215/9780822384687-001

-, ed. 2003b. States of Memory: Continuities, Conflicts, and Transformations in National Retrospection. Durham: Duke UP.

PARKs, Suzan-Lori. 1995a. "From Elements of Style." In Parks 1995c, 6-18.

—. 1995b. "Possession." In Parks 1995c, 3-6.

-. 1995c. The America Play and Other Works. New York: Theatre Communications Group.

PARKS, Suzan-Lori and Adrienne Kennedy. 1996. "Adrienne Kennedy.” BOMB 54: 4245.

Perry, Imani. 2019. Breathe: A Letter to My Sons. Boston: Beacon Press.

Phelan, Peggy. 1993. Unmarked: The Politics of Performance. New York: Routledge. 
RedDy, Chandan. 2011. Freedom with Violence: Race, Sexuality and the US State. Durham: Duke U.P. https://doi.org/10.1215/9780822394648

RutHERFord, Jonathan, ed. 1990. Identity: Community, Culture, Difference. London: Lawrence and Whishart.

Schramm, Katharina. 2011. "Landscapes of Violence: Memory and Sacred Space." History \& Memory 23 (1): 5-22. https://doi.org/10.2979/histmemo.23.1.5

Sollors, Werner. 1991. "Owls and Rats in the American Funnyhouse: Adrienne Kennedy's Drama.” American Literature 63 (3): 507-532.

https://doi.org/10.2307/2927246

SONTAG, Susan. 2004. "Regarding the Torture of Others." New York Times. https:// www.nytimes.com/2004/05/23/magazine/regarding-the-torture-of-others.html [Accessed online on Sept. 10, 2020]

Tolan, Casey. 2021. "DC Police Made Far More Arrests at the Height of Black Lives Matter Protests than during the Capitol Clash" CNN. https://edition.cnn. com/2021/01/08/us/dc-police-arrests-blm-capitol-insurrection-invs/index.html [Accessed online on Jan. 9, 2021]

VORLICKY, Robert. 1997. "Sleep Deprivation Chamber by Adrienne Kennedy and Adam Kennedy” Theatre Journal 49 (1): 67-69. https://doi.org/10.1353/tj.1997.0019 